\title{
Article
}

\section{Sciatica (lumbar radiculopathy)}

\author{
Nuttall, Dilyse
}

Available at http://clok.uclan.ac.uk/21254/

Nuttall, Dilyse ORCID: 0000-0002-0561-5229 (2017) Sciatica (lumbar radiculopathy). Nurse Prescribing, 15 (1). p. 12. ISSN 2052-2924

It is advisable to refer to the publisher's version if you intend to cite from the work.

10.12968/npre.2017.15.1.12

For more information about UCLan's research in this area go to

http://www.uclan.ac.uk/researchgroups/ and search for < name of research Group>.

For information about Research generally at UCLan please go to http://www.uclan.ac.uk/research/

All outputs in CLoK are protected by Intellectual Property Rights law, including Copyright law. Copyright, IPR and Moral Rights for the works on this site are retained by the individual authors and/or other copyright owners. Terms and conditions for use of this material are defined in the policies page.

\section{CLoK}

Central Lancashire online Knowledge www.clok.uclan.ac.uk

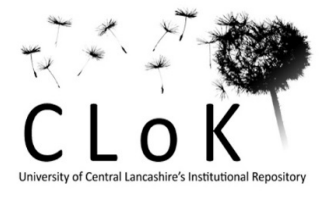




\section{Calculation Skills: Sciatica (lumbar radiculopathy)}

Sciatica results from irritation or compression of the nerve root in the lumbosacral spine, with symptoms including pain, numbness and tingling which can extend down the back of the leg as far as the toes (NICE, 2015). The provision of adequate pain relief is a key aspect of the management of sciatica.

Damian, a 46 year old engineer, has been diagnosed with sciatica following a recent MRI scan which, showed herniation of an intervertebral disc causing nerve root compression.

Question 1.

A step-wise approach to the prescribing of analgesia is recommended in the treatment of sciatica, with paracetamol or a non-steroidal anti-inflammatory drug (NSAID) such as ibuprofen suggested as first line treatments (NICE, 2015). Damian was prescribed the maximum dose of paracetamol $1 \mathrm{~g}$, to be taken 4-6 hourly, to a maximum of $4 \mathrm{~g}$ in 24 hours. He was given an appointment for review three days later.

(i) What is the maximum number of paracetamol 500mg tablets that Damian could take in the three days treatment?

(ii) On day 1, Damian took his first dose at 6am, his second at $11 \mathrm{am}$, his third at $5 \mathrm{pm}$ and his final dose at $9 \mathrm{pm}$. What was the average time interval between doses?

(iii) What time could Damian take his first tablet on day 2?

Question 2.

At his review appointment, Damian reported minimal effect from the paracetamol and was prescribed ibuprofen $400 \mathrm{mg} 4$ times daily, which was to be taken in combination with his current paracetamol regime. He was prescribed enough paracetamol $500 \mathrm{mg}$ tablets and ibuprofen $400 \mathrm{mg}$ tablets to last the six days until his next appointment.

(i) How many tablets will Damian be taking daily?

(ii) What proportion (as a fraction) of the total tablets prescribed will be ibuprofen?

\section{Question 3.}

Damian reported limited effects from the combination therapy and it was decided that, in accordance with NICE (2015) guidance, he would be prescribed a weak opioid as the next step of his treatment. He was prescribed codeine phosphate, which has a maximum daily dose of $240 \mathrm{mg}$. Damian took $30 \mathrm{mg}$ 4 hourly initially but had to increase the dose to $60 \mathrm{mg}$ each time on day 3 and onwards.

How many codeine phosphate 30mg tablets did Damian use for the first 7 days? 


\section{Question 4.}

Despite previous measures, Damian's pain remains uncontrolled and he is prescribed a drug for neuropathic pain. Local policy suggests either gabapentin or amitriptyline hydrochloride as the drug of choice. Table 1 provides an example regime for gabapentin, in line with the Joint Formulary Committee (2016).

\begin{tabular}{|l|l|}
\hline Table 1 & Dose of Gabapentin \\
\hline Day & 300mg 3 times a day \\
\hline $1 \& 2$ & $400 \mathrm{mg} 3$ times a day \\
\hline $3,4 \& 5$ & $500 \mathrm{mg} 3$ times a day \\
\hline $6,7 \& 8$ & $600 \mathrm{mg} 3$ times a day \\
\hline $9,10 \& 11$ & $700 \mathrm{mg} 3$ times daily \\
\hline $12,13 \& 14$ &
\end{tabular}

Capsules are available in strengths of $100 \mathrm{mg}, 300 \mathrm{mg} \& 400 \mathrm{mg}$. If all strengths were available, what would be the minimum number of capsules that could be taken for the full 14 days treatment?

Question 5.

Damian was prescribed amitriptyline and has had the dose titrated as indicated in table 2.

\begin{tabular}{|l|l|}
\hline Table 2 \\
\hline Week & Daily dose of Amitriptyline \\
\hline 1 & $10 \mathrm{mg}$ \\
\hline 2 & $20 \mathrm{mg}$ \\
\hline 3 & $30 \mathrm{mg}$ \\
\hline 4 & $50 \mathrm{mg}$ \\
\hline $5-6$ & $75 \mathrm{mg}$ \\
\hline
\end{tabular}

(i) By what percentage did the dose increase from week 1 to week 6?

(ii) What is the total dose of amitriptyline taken over the 6 week period?

(iii) Treatment is to be discontinued gradually over a four week period. If the dose is reduced by one third in week 7 , a further $2 / 5^{\text {th }}$ in week 8 and a further $3^{\text {rd }}$ in week 9 , what daily dose will Damian be taking in week 9 ?

\section{$\underline{\text { Answers }}$}

\section{Question 1}

(i) Daily dose $=8$ tablets. Three days $=8 \times 3=24$

(ii) Interval dose 1-2 $=5 \mathrm{hrs}$, dose $2-3=6 \mathrm{hrs}$, dose $3-4=4 \mathrm{hrs}$ $5+6+4=15 \mathrm{hrs} \quad 15 \mathrm{hrs} \div 3=5 \mathrm{hrs}$

(iii) First dose taken at $6 \mathrm{am}$ and maximum dose taken by $9 \mathrm{pm}$. $24 \mathrm{hr}$ period ends at $6 \mathrm{am}$. First dose on day 2 can be taken at 6am or after. 


\section{Question 2}

(i) 8 (paracetamol) +4 (ibuprofen) $=12$ tablets daily

(ii) Total paracetamol tablets $=8$ (tablets daily) $\times 6$ (days) $=48$

Total ibuprofen tablets $=4$ (tablets daily) $\times 6$ (days) $=24$

Total $=48+24=72$

$24 / 72=1 / 3$

\section{Question 3}

Days $1 \& 2=6$ tablets daily $\times 2=12$ tablets

Days 3-7 = 8 tablets daily (maximum daily dose) $\times 5=40$ tablets

Total taken $=12+40=52$ tablets

\section{Question 4}

Days $1 \& 2=300 \mathrm{mg}$ capsule $\times 3$ per day / total 6 capsules

Days $3,4 \& 5=400 \mathrm{mg}$ capsule $\times 3$ per day / total 9 capsules

Days $6,7 \& 8=400 \mathrm{mg}$ capsule $\times 3$ plus $100 \mathrm{mg}$ capsule $\times 3$ per day / total 18 capsules

Days $9,10 \& 11=300 \mathrm{mg}$ capsule $\times 2 \times 3$ per day / total 18 capsules

Days $12,13 \& 14=300 \mathrm{mg}$ capsule $\times 3$ plus $400 \mathrm{mg}$ capsule $\times 3$ per day $/$ total 18 capsules

Total for 14 day period $=6+9+18+18+18=69$

\section{Question 5.}

(i) Week $1=10 \mathrm{mg}(100 \%)$

Week $6=75 \mathrm{mg}=65 \mathrm{mg}$ greater than day 1

$65 \mathrm{mg}=10 \times 6.5=100 \% \times 6.5=650 \%$ increase

(ii) Total dose taken $=(7 \times 10)+(7 \times 20)+(7 \times 30)+(7 \times 50)+(14 \times 75)=70+140+210+350$ $+1050=1820 \mathrm{mg} / 1.82 \mathrm{~g}$

(iii) Week 7: Reduction of $75 \mathrm{mg}$ by a $3^{\text {rd }}=50 \mathrm{mg}$ Week 8: Reduction of $50 \mathrm{mg}$ by $2 / 5^{\text {th }}=30 \mathrm{mg}$ Week 9: Reduction of $30 \mathrm{mg}$ by a $3^{\text {rd }}=20 \mathrm{mg}$ Daily dose in week $9=20 \mathrm{mg}$ 


\section{$\underline{\text { References }}$}

Joint Formulary Committee (2016) BNF 71, London: BMJ Group \& Pharmaceutical Press

NICE (2015) Clinical Knowledge Summaries: Sciatica (lumbar radiculopathy), available at: https://cks.nice.org.uk/sciatica-lumbar-radiculopathy 